\section{Carta ao Editor: Comentários a Ensino e Educação} Médica

Letter to the Editor: Comments to Training and Medical Education

Palavras-chave: Educação Médica; Portugal

Keywords: Education, Medical; Portugal

Foi uma boa iniciativa da Acta Médica Portuguesa dedicar um número à Educação e Pedagogia Médicas.

É nosso entendimento que a investigação desenvolvida neste contexto deve ser incentivada no sentido de promover uma maior plasticidade e evolução no Ensino Médico em Portugal.

Lamentando não ter tido conhecimento desta iniciativa, não quero deixar de dar o contributo da minha experiência nesse campo.

Poderemos ter estudado imenso, pensado muito; assistido a dez congressos e feito sete cursos de pedagogia médica, poderemos ter 20 anos de experiência (os erros do primeiro ano repetidos 20 vezes perguntava Gouveia Monteiro) que, se não tivermos assistido à colheita de história clínica por um aluno do último ano de Medicina não poderemos avaliar o processo de ensino/aprendizagem de que somos responsáveis.

Só quando deixei de ser regente de uma Cadeira clínica e comecei a acompanhar essas colheitas me dei conta disso.

«Rien. Tu ne sais rien

Non, tu n'as rien vu à Hiroshima» ${ }^{1,2}$

Desde há anos que, a convite do Professor responsável, regressei à minha actividade de 'assistente' de alunos de Pediatria dando 'aulas práticas' com um doente. Desde que o sexto ano tem o carácter prático ('profissionalizante') actual que assumo o papel de tutor - assistindo à colheita de histórias clínicas feitas por alunos de Medicina que já tiveram a cadeira de Pediatria. Escolho os doentes mais adequados para o nível e o objectivo pedagógico destes alunos - nem os internados, demasiado graves ou complexos, nem os que vêm à consulta ou ao Serviço de Urgência, por razões de conveniência. Escolho dentre os hospitalizados de curta duração (Unidade de Internamento de Curta Duração/Serviço de Observação anexa à Urgência), acompanhados pela mãe ou equivalente. Obtida a aquiescência para esta simulação de uma consulta, assisto ao desenrolar do processo e intervenho de vez em quando para que cada um faça a autocrítica do seu desempenho, o método mais adequado para este nível de aprendizagem da técnica e das atitudes. Sugiro dois critérios - o critério médico clássico, que eles conhecem, e o da mãe e da criança como elas valorizarão o desempenho desses jovens médicos. Aproveitando a minha experiência de anos a observar como é que os quase médicos fazem histórias clínicas, escrevi este texto. Para que não repitam os erros que a minha geração cometeu ao longo da vida; que façam outros mas não os mesmos. ${ }^{3,4}$
Se algo aprendi sobre ensino em Medicina, que não tenho visto sublinhado, é óbvio e simples.

1. Nenhum docente de Medicina poderá avaliar o resultado do seu ensino sem ter assistido a uma colheita de história clínica dos alunos (bastarão três ou quatro); colheita e discussão do relatório escrito dessa história. (Os docentes das cadeiras pré clínicas deverão assistir à discussão - escolhidos de acordo com o tipo de problema; bastará que cada um assista a duas ou três discussões por ano). Em cada uma destas consultas simuladas poderão participar até três alunos - um interroga, outro inspecciona e o terceiro toma notas e, depois, termina o exame.

Quase todas $(99,9 \%)$ as mães dos pequenitos doentes aceitam participar ... e a maioria até agradece.

2. Todo o aluno de Medicina deverá realizar uma história clínica sob constante observação de um docente, pelo menos duas vezes por ano, nos anos clínicos do curso. Aqui, os professores jubilados poderiam ter um papel muto importante tanto para os alunos como para eles.

É indispensável que todos os docentes das cadeiras clínicas o façam (e não só psicólogos como na Faculdade de Medicina da Universidade do Porto) para que, além de ser avaliada a crucial relação com o doente (e com a mãe) avaliem também a pertinência das perguntas e a qualidade do raciocínio clínico. Poderão assim rever o processo do seu ensino - teórico e prático; os assistentes também deverão participar nessa prova que avalia tanto o resultado como o processo do ensino e consequente aprendizagem. Para evitar que só tarde demais se deem conta dos bem-intencionados erros cometidos, como Sir Alex Guinness no final de "A Ponte do Rio Kwai" de David Lean.

3. Todo o aluno de Medicina deverá ter passado por duas das experiências seguintes: inscrever-se, esperar e submeter-se a uma consulta num centro de saúde e ser internado num hospital (com sintomas reais ou fictícios). Os centros de saúde e os hospitais ligados ao ensino saberão que tal vai acontecer mas não saberão quais.

4. Todo o aluno dos últimos anos deverá 'adoptar' um doente - na consulta ou internado - e segui-lo durante um ano - sempre que regressar (será seu guia) ou em casa - por telefone mensal e visitas domiciliárias (duas ou mais). Esta norma que os alunos de Pediatria da Faculdade de Medicina da Universidade de Coimbra seguem, aprendi-a com o Prof. Norberto T. Santos, que a trouxe de Moçambique.

Esta é a indispensável reforma do ensino que acoIherá bem outros bons processos complementares referidos no último número da AMP.

5. Sem esquecer que os alunos olham para os docentes na esperança de encontrar mestres - os modelos que irão seguir. João Lobo Antunes falou do 'curriculum oculto'; mutatis mutandis também o ensino médico tem de evitar os Prof.s Frei Tomaz ou Vasco Moscoso 
de Aragão.

Tive bons professores, alguns notáveis mas meus mestres foram meu pai, Henrique Pereira da Mota, clínico geral em Porto da Lage (depois de ter sido Pantaleão em Coimbra) e Nicolau da Fonseca, mestre de Pediatria em Coimbra - ambos licenciados com 14 valores; e o Generall Kutusov (Tolstoi, Guerra e Paz), mestre de estratégia. 'Os seus actos, todos, sem excepção alguma, visaram este tríplice objectivo: concentrar todas as suas forças no intuito

\section{REFERÊNCIAS}

1. Duras M. Hiroshima mon amour. [Consultado 2015 jan 15]. Disponível em http://www.marguerite-duras.com/Hiroshima-mon-amour.php

2. Mota HC. Hiroshima pedagógica. ROM. 2015;157:62.

3. Mota HC. Para uma história clínica (I). Acta Pediatr Port. 2011;42:43-8 de fazer frente aos Franceses, vencer o inimigo e por fim expulsá-lo da Rússia, minorando quanto possível os sofrimentos do povo e do exército. ${ }^{5}$

Sem bons modelos não há reforma do ensino que vingue.

Em memória de outro excelente modelo, JM Pinto Correia, fundador da Sociedade Portuguesa de Educação Médica.

4. Mota HC. Para uma história clínica (II). Acta Pediatr Port. 2011;42:84-9

5. Tolstoi L. Guerra e paz. Tradução de Isabel da Nóbrega e João Gaspar Simões. Lisboa: Europa-América; 2002.

\section{Henrique Carmona da MOTA $\square^{1,2}$}

1. Hospital Pediátrico. Centro Hospitalar e Universitário de Coimbra. Coimbra. Portugal.

2. Faculdade de Medicina. Universidade de Coimbra. Coimbra. Portugal.

Autor correspondente: Henrique Carmona da Mota. hcmota@ci.uc.pt.

Recebido: 09 de janeiro de 2017 - Aceite: 10 de janeiro de 2017| Copyright @ Ordem dos Médicos 2017

http://dx.doi.org/10.20344/amp.8644 